\title{
Learning Translation and Multi-culture to Reduce Social Conflict
}

\author{
Aris Wuryantoro $\bowtie$; Universitas PGRI Madiun
}

\begin{abstract}
This study aims to describe the role of learning translation with enhancing multiculture understanding to reduce social conflict in society. This study used descriptive qualitative method by using documentation technique in collecting data. The source of the data are documentations in the form of intralingual and interlingual translation. The result of the study reveals that translation has four aspects, there are meaning, grammatical structure, communication situation, and cultural context. Besides, translation is closely related to cultural context aspect because translation contains at least cultural aspect from source language and target language. The researchers conclude that learning translation can enhance multi-culture in order to reduce social conflicts. The language used by one society automatically shows its language user or its social identity. The researcher concludes that by mastering language and culture of one society as a part of learning translation, we can reduce social conflict which mainly caused by misunderstanding toward the used language and culture.
\end{abstract}

Keywords: Translation, social conflict, multi-culture.

\allaam_71@yahoo.co.id

Citation: Wuryanto, A. (2020). Learning translation and multi-culture to reduce social conflict. Social Sciences, Humanities and Education Journal (SHE Journal), 1(1), 26 - 31.

\section{(cc) BY-NC-SA}

Published by Universitas PGRI Madiun. This work is licensed under the Creative Commons AttributionNonCommercial-ShareAlike 4.0 International License. 


\section{INTRODUCTION}

One day, there was emotionally conversation in a taylor, Borobudur Tailor, between mas Dony and pak Gandung. Mas Dony is one of Borobudur Tailor workers who work to pak Gandung. Dony comes from Demak (Central Java), while pak Gandung comes from Jombang (East Java). With a loud voice and a reddened face, pak Gandung asked his clothes that were hanging behind the door in a mess. While holding the shirt shown to Dony, Pak Gandung said;

\begin{tabular}{|c|c|}
\hline Pak Gandung & $\begin{array}{l}\text { :"Sopo sing gawe } \\
\text { klambiku?" }\end{array}$ \\
\hline Mas Dony & $\begin{array}{l}\text { :"Kulo pak, kulo ingkang } \\
\text { ndamel rasukan niku." }\end{array}$ \\
\hline Pak Gandung & $\begin{array}{l}\text { :"Wani-wanine kowe } \\
\text { gawe klambiku?!” }\end{array}$ \\
\hline Mas Dony & $\begin{array}{l}\text { :Inggih pak, kulo sing } \\
\text { ndamel, kan kulo ingkang } \\
\text { njait rasukan niku". }\end{array}$ \\
\hline Pak Gandung & $\begin{array}{l}\text { :"ooooo.... Nggih sampun, } \\
\text { tak kiro kowe sing } \\
\text { nganggo }\end{array}$ \\
\hline
\end{tabular}

Based on a conversation with a high tone and a blushing face shows the anger of one of the speakers involved in the conversation. In this case the speaker is Pak Gandung. The tension that occurred in the conversation showed a misunderstanding between pak Gandung and mas Dony, which started from the words gawe (Javanese ngoko) or ndamel (Javanese kromo inggil/high manner).

The word gawe or ndamel in Javanese has two perceptions for different meanings between the people of Central Java and East Java. The word gawe or ndamel for the people of East Java has the meaning "to use, wear, or by", while for the people of Central Java the word gawe or ndamel has the meaning to make or produce. The sentence, Sopo sing gawe klambiku? which asked by pak Gandung means Who wore my shirt? On the other hand, kulo ingkang ndamel rasukan niku as the answering by mas Dony to the Gandung's asking means I sew that shirt, sir because mas Dony has sawn pak Gandung's shirt so he answered, Kulo pak (I was). So, it can be serious problem using word gawe or ndamel for Javanese if the speaker or the listener do not understand where they come from, from East Java or Central Java. It can be avoided the misunderstanding for the speaker and listener if the speaker has knowledge about their cultures. To bridge the misunderstanding between speaker and listener, it needs translator to translate from source language into target language. Wuryantoro (2014) states that kill two birds with one stone is the most appropriate proverb to talk about translation. Translation consists of transferring the meaning from one language into another language. Studying translation means studying two languages at once, i.e. source language and target language which are influenced by its cultures.

Larson (1984) states, ..."translation consists of transferring the meaning of the source language into the receptor language. This is done by going from the form of the the first language to the form of a second language by way of semantic structure. It is meaning which is being transferred and must be held constant. Only the form changes". It means that translation primarily transfers the meaning from source langguage into target language by considering the form of target language. Besides, the translation focuses on semantic element. The form or grammatical structure must be appropiate with the form of target language's form in order to make the translation as natural as possible. Someone who translates text is translator, but not every one who translates the text is usually translator. Wuryantoro (2014) states that translator is someone who has mastered source language and target language well and also has experiences in professional 
training about techniques of translation to transfer the written messages completely from one language into another language.

Larson, furthermore, says, "Translation, then, consists of studying the lexicon, grammatical structure, communication situation, and cultural context of the source language text,...". There are four aspects that must be paid attention by the translator, one of them is cultural aspect. Meaning in the target language should be match with the culture in the target language too in order to make the translation text is acceptable in the target language. In other word, the translator have to master the cultures contained both in source language and in target language, as stated by Vermeer (in Katan, 1999), the translator as bicultural.

The cultural context of the source language should be adapted to the cultural context of the target language, such as the word "rice" in English (source language) translated into Indonesian (target language) into various words or meanings, such as padi (if it is still in paddy field or still stemmed), beras (when it is ground / ground but not yet cooked), and nasi (when it is cooked/ready to eat). When the word "rice" is translated into the Javanese language, it will be much more diverse again the meaning it has, such as rungge, jatha, menir, and upo.

Wong and Shen (1999) state that there are three factors influence the translation process, namely linguistic, culture, and personal factor. Linguistic factor has important and direct influence in translation process, such as phonological, lexical, syntactical, textual factor. Culture factor also has important influence in translation process, which contains intra-culture and inter-culture factor. Condition of psychological and professional translator has direct influence to translation text. Different translator (different personal) will produce different translation in target language text, even from the same text in source language. Personal factor includes personal attitude and personal competence.

Culture factor plays the vital role in translation process. It consists of interculture and intra-culture factor. Interculture factor includes specific expression in a culture, aesthetic differences, political interferences, and ethical influences; and intra-culture factor includes strategic orientation and style of time in the culture of the target language. Lotman (in Basnett, 1992) states, "No language can exist unless it is stepped in the context of culture". This statement supported by Nida. Nida (1993:i) describes, "The role of language within a culture and the influence of the culture on the meanings of words and idioms are so pervasive that scarcely any text can be adequately understood without careful consideration of its cultural background". Wuryantoro (2014) states that translation is the activity of transferring the meaning of the source language into the target language, be it is the first language, the second language, the foreign language or even in the same language. Cultural elements in the form of ideas, habits / activities, artifacts, and environment / ecology can not be separated from the translation. These cultural elements are contained in the languages involved in translation. Learning translation by itself is also learning the culture.

Jakobson (in Munday, 2001) divides translation into three categories, namely: (1) intralingual translation is the translation in the same language, (2) interlingual translation is the translation from one language into another language, and (3) intersemiotic translation is the translation from one form into another form, such as in the form of music, film, or painting.

\section{METHODS}

This research used descriptive qualitative method with documentation technique in data collection and content 
for data analysis. The sources of data used are documentations in the form of intralingual and interlingual translation. The intralingual translation involves the translation either in Indonesian or in Javanese. While, the interlingual translation involves the translation English, Indonesian and Javanese. These documents are analyzed by using theories of translation and translation of culture. Data obtained analyzed by using interactive model.

\section{RESULT AND DISCUSSION}

As stated before that intralingual translation is the translation in the same language. Wuryantoro (2014) states that when we are reading the text, we are also translating it. The purposes of the writer of the intralingual text to the reader are promotion, announcement, socialization, prohibition, symbol of identity, and joking.

\section{Example 1. Ngebut Benjut (Speed is livid)}

This is an announcement plastered in front of the alley or narrow street. When we are reading this text, we are automatically translating what the text means. This text functions as the announcement to the rider not to ride in high speed because there is a narrow street or alley which has limited area to ride and there are many children who are playing in the alley. The rider who runs in this alley must be in low speed, if he still runs in high speed (ngebut) he can be livid (benjut). He can be benjut whether he crashed something in the alley and will be benjut in his head, or he will be benjut by hit or beaten by the community who live in this alley.

Example 2. Pulang Malu, Gak Pulang Rindu (going home is ashamed, not going home is missing)

This text is found on a truck, either on the back or in the front of the truck.
Reader can translate that this paper is an expression of the truck driver in a dilemma. Pulang Malu, the driver wants to go home because he did not bring home a lot of money to be handed over to his wife and son, but Gak Pulang Rindu has long time since left his wife and children at home to take luggage out of town for days.

On the other hand, interlingual translation is the translation from one language into another language. Let us study this examples below.

Example 1. Kill two birds with one stone.

How is the translation in Indonesian? There are two translation alternatives, as follows:

\section{a. Membunuh dua burung dengan satu batu. \\ b. Sambil menyelam minum air.}

Which one is true? Both translations are true. But we need to review from the message in the source language and good translation criteria. The message in the source language is two jobs completed in one action or once work for two jobs can be completed. In translation (a), membunuh dua burung dengan satu batu, the criteria of accuracy can be met because all information is represented in the translation. The criteria of readability, already qualified because the translation is easy to read or understood by translation readers. What about the criteria of acceptability or naturalness? According to the writer's interpretation $a$ of the criteria of acceptability is still lacking or even unacceptable since the form of the source language text, the proverb, should also be translated into the target language proverb as well. What about the translation b? In accordance with the message contained in the source language, in the opinion of the author, the translation (b) is eligible to be a good translation. This translation fulfils the criteria of accuracy, readability, and 
acceptability. All messages have been conveyed, the translation is easy to understand and acceptable because it is suitable to the culture of target language, namely Indonesian proverb. So the proverb of "Kill two birds with one stone" is appropriately translated into sambil menyelam minum air.

How about the translation below. Example. 2.

a. Bu Ratih mundhut iwak Lele sekilo.

b. Bu Ratih mundhut iwak pithik sekilo.

In example (a), the meaning of iwak is "fish" that lives in water, catfish. So the example (a) when translated into Indonesian becomes $\mathrm{Bu}$ Ratih membeli ikan Lele satu kilogram (Mrs. Ratih buys catfish one kilograms). How about example (b) when translated into Indonesian and iwak means ikan? Obviously the translation will feel strange, Bu Ratih membeli ikan ayam satu kilogram (Mrs Ratih buys fish chicken one kilograms). Why does it happen? It happens because there are different points of view on the word iwak. Iwak in Javanese is in general, ikan dan daging (fish and meat), whereas in the Indonesian language is a particular meaning, the word iwak means ikan yang hidup di air (fish that lives in water).

There are some particular meanings or special used for words in Javanese, otherwise general meaning in Indonesian or English. For example, the word "washing" in English if it is translated into Indonesian becomes mencuci. There are some words or terms in Javanese to replace the word "washing" or mencuci. The words or terms in Javanese for the word "washing" are namely umbah-umbah, asahasah/isah-isah, mususi, jamas, and ngguyang. The term umbah-umbah is used to clothes, for example Ibu saweg umbah-umbah klambi wonten sumber (Mother is washing clothes in the well). The word isah-isah is used to plates or glassware, for example Mbak Unang lagi asah-asah piring neng pawon (Mbak
Unang is washing plates in the kitchen). The word mususi is used to rice, for example Bibi saweg mususi beras wonten sumber (Aunt is washing rice in the well). The word jamas is only used to traditional weapon, for example $M b a h$ Rebo njamas keris pendak malem siji Suro (Mbah Rebo jamas keris/washing keris every night one Suro). The word raup is used to face, Adikku lagi raup merga nembe tangi turu (My younger brother is washing face because just woke up). The word ngguyang is used to animal, for example Paman Karso ngguyang kebo neng kali (Uncle Karso ngguyang buffalo in the river).

Like as the case stated in the introduction before, there is a conversation between Jajang and Jono. Jajang comes from Tasikmalaya (Sundanese) and Jono comes from Solo (Javanese). One day, Jajang and Jono are working on building works. Jajang at the top as he was renovating the broken window, Jono helps Jajang wait below. When Jajang was nailing, his hammer fell. Jajang immediately shouted to Jono,

Jajang : "Jono, cokot atuh martilna!"
Jono : "Cokot, atos kang. Aku moh
nyokot martile" Jajang asks in an angry tone while pointing to the hammer, "Jono, cokot atuh martilna!"

Jono : "Moh kang, atos"

Jajang : "Atos, atos, anjeun can cokot martilna"

Because of misunderstandings, they both ended up fighting to defend their opinions. but this is all because of the lack of meaning of the word they use, cokot. The word cokot in Sundanese language means take, while the word cokot in Javanese means bite. Whereas, the word atos in Javanese means hard, the word atos in Sundanese is already.

The case above is one example because of the ignorance of the perpetrators of communication. This is a small example of social conflict caused by the limitations of cultural knowledge. It 
can be prevented if each speaker has a cultural knowledge contained in the language used. The speaker has to understand his/her audience or participant. Besides, the speaker also has to understand the participant's culture background. The participant's culture background can be identified by his/her language. It is important to understand cultural knowledge in taking communication, such as in translation study. In studying translation, we study lexicon, grammatical structure, communication situation, and cultural context. In learning translation, we study cultural context both in source language and in target language, even the culture background of the source language text writer. Wuryantoro (2014) states that dengan belajar penerjemahan dengan sendirinya juga belajar budaya (learning translation is automatically learning cultures). It can be said that translation can reduce the social conflict caused by limitation of cultural knowledge.

\section{CONCLUSION}

Based on the examples above, the researchers conclude that translation studies not only languages but also cultures even multi-culture because the translation involves at least two languages and two cultures. The languages are source language and target language, and the cultures are source culture and target culture. Learning translation can enhance cultural understanding because cultural context is one of translation areas.

\section{REFERENCES}

Basnett-McGuire, S. (1991). Translation Studies. New York: Metheun \& Company Limited.
Katan, D. (1999). Translating Culture. Manchester: St Jerome Publisher.

Larson, M.L. (1984). Meaning-Based Translation: A Guide to Cross Language Equivalence. Lanham: University Press of America.

Munday, J. (2001). Introducing Translation Studies: Theories and Applications. London: Routledge.

Nida, E. A. (1993). Language, Culture and Translating. Shanghai: Shanghai Foreign Language Education Press.

Subardi, A. \& Sujarwoko. (2015). Pembelajaran Bahasa Melalui Penerjemahan Pada Bahasa Stiker: Suatu Kajian Penerjemahan Intralingual. Proceeding of Seminar Nasional Penelitian Bahasa, Sastra dan Pengajarannya Dewasa Ini; Universitas Nusantara PGRI Kediri, Indonesia. Kediri: Indonesian Language Education Program of Universitas Nusantara PGRI Kediri.

Wong, D, \& Shen, D. (1999). Factors Influencing the Process of Translating. Meta: Translator Journal. 44(1), 78-100.

Wuryantoro, A. (2014). Kajian Proses Penerjemahan dan Kualitas Terjemahan Teks Hukum dan Teks Ilmiah Bidang Hukum Karya Penerjemah Tersumpah. Dissertation. Surakarta: Postgraduate Program of Sebelas Maret University.

Wuryantoro, A. (2014). Belajar Budaya Melalui Penerjemahan. (Eds)Fafi, I, et.al,. Membangun Budaya Literasi. Surabaya: UNESA University Press. Wuryantoro, A. (2015) Pernak-Pernik Penerjemahan. Madiun: Institut Press IKIP PGRI Madiun. 